\title{
CORRECTION
}

Open Access

\section{Correction to: HPV DNA in saliva from patients with SCC of the head and neck is specific for p16-positive oropharyngeal tumours}

\author{
Jason K. Wasserman ${ }^{1}$, Ryan Rourke², Bibianna Purgina ${ }^{1}$, Lisa Caulley², Jim Dimitroulakos ${ }^{3}$, Martin Corsten ${ }^{4}$ \\ and Stephanie Johnson-Obaseki ${ }^{*}$
}

\section{Correction}

Following publication of the original article [1], the authors reported an error in one of the author names. In this Correction the incorrect and correct author names are listed.

Incorrect author name upon publication:

- Jim Dimitroulakis

The correct author name:

- Jim Dimitroulakos

\section{Author details}

'Department of Pathology and Laboratory Medicine, Division of Anatomical Pathology, The University of Ottawa and The Ottawa Hospital, Ottawa, ON, Canada. ${ }^{2}$ Department of Otolaryngology - Head and Neck Surgery, The University of Ottawa and The Ottawa Hospital, Ottawa Hospital-General Campus S3, 501 Smyth Rd, Ottawa, ON K1H 8L6, Canada. ${ }^{3}$ Ottawa Hospital Research Institute, Ottawa, ON, Canada. ${ }^{4}$ Aurora St. Luke's Hospital, Milwaukee, WI, USA.

Received: 13 July 2018 Accepted: 13 July 2018

Published online: 02 August 2018

\section{Reference}

1. Wasserman, et al. HPV DNA in saliva from patients with SCC of the head and neck is specific for p16-positive oropharyngeal tumours. J Otolaryngol Head Neck Surg. 2017;46:3. https://doi.org/10.1186/s40463-016-0179-6.

\footnotetext{
* Correspondence: sjohnsonobaseki@gmail.com

${ }^{2}$ Department of Otolaryngology - Head and Neck Surgery, The University of Ottawa and The Ottawa Hospital, Ottawa Hospital-General Campus S3, 501 Smyth Rd, Ottawa, ON K1H 8L6, Canada

Full list of author information is available at the end of the article
}

(c) The Author(s). 2018 Open Access This article is distributed under the terms of the Creative Commons Attribution 4.0 International License (http://creativecommons.org/licenses/by/4.0/), which permits unrestricted use, distribution, and reproduction in any medium, provided you give appropriate credit to the original author(s) and the source, provide a link to the Creative Commons license, and indicate if changes were made. The Creative Commons Public Domain Dedication waiver (http://creativecommons.org/publicdomain/zero/1.0/) applies to the data made available in this article, unless otherwise stated. 